DOI: http://dx.doi.org/10.4314/star.v4i2.35 ISSN: 2226-7522(Print) and 2305-3372 (Online) Science, Technology and Arts Research Journal Sci. Technol. Arts Res. J., April-June 2015, 4(2): 252-258 Journal Homepage: http://www.starjournal.org/

Original Research

\title{
Evaluation of Supply Variability of Household Water use in Ilorin Metropolis, North Central Nigeria
}

\author{
Ayanshola, A.M ${ }^{1^{*}}$, Sule, B.F ${ }^{1}$ and Mandal $\mathrm{K}^{2}$ \\ ${ }^{1}$ Department of Water Resources and Environmental Engineering, University of Ilorin, P.M.B. 1515, \\ Ilorin, Nigeria
}

${ }^{2}$ National Institute of Science, Technology and Development Studies, New Delhi, India

\begin{tabular}{ll}
\hline \multicolumn{1}{c}{ Abstract } & Article Information \\
\hline This study focused on the evaluation of supply variability of household water use in llorin, & $\begin{array}{l}\text { Article History: } \\
\text { Received :07-04-2015 }\end{array}$ \\
Nigeria. The field work of the study involved the use of structured questionnaire and & $\begin{array}{l}\text { Revised } \\
\text { installation of water meters to obtain data on household water supply in selected houses }\end{array}$ \\
within the metropolis. The findings of the study revealed that the estimated average daily & Accepted $: 19-06-2015$ \\
\cline { 2 - 2 } water use was 86.22 liters/capita/day which is lower than W.H.O. standard of 120 & Keywords: \\
liters/capita/day for developing nations. However, the measurement from installed water & Variability Index \\
meters indicated that average water use can be as high as 139.44 liters/capita/day. The & Variation \\
analysis further showed that the variability index is inversely proportional to the & Water Supply \\
percentage number of households indicating that increase in population will reduce the & Water Use \\
\cline { 2 - 2 } level of service provided by the supplier. Hence, there is the need to put in place a & *Corresponding Author: \\
framework to enhance improvement of water supply to the metropolis in order to achieve & Ayanshola, A.M \\
a higher index closer to unity. The use of meters to obtain accurate household water & \\
consumption data is recommended so that the necessary baseline data on effective & E-mail: \\
water demand/supply management can be generated. & engramayanshola@gmail.com \\
Copyright@2015 STAR Journal, Wollega University. All Rights Reserved. &
\end{tabular}

\section{INTRODUCTION}

Majority of Nigerian urban population has no access to improved drinking water. This can be linked to rapid urbanization which has led to increase in urban population and greater demand for water supply and sanitation services in the country.. Access to drinking water has become a vital and persistent environmental health challenge in developing countries (Ruiz-Mier and Ginneken, 2006; Okonkwo, 2010). This phenomenon has placed pressure on public water utilities due to mismatch between demand and supply of potable water in our society. Tobieh, et al. (2012) opined that increase in incomes and growth of urban populations have placed pressure on municipal water supply and sewage treatment facilities and water authorities are struggling to cope with rising deficits and increasingly stringent water quality regulations. They further argued that the problem facing water policymakers and water utility managers is a lack of adequate information to determine the performance of price and non-price policy instruments in their communities. In most Nigerian urban cities, where a large proportion of household water demand is fulfilled by the use of alternative sources to public water supply, offering a continuous supply of water can therefore have two potential goals; to meet the water needs for the citizenry and at the same time to reduce the cost that will be incurred in sourcing for alternative sources that can be sometimes much more expensive (Ayanshola et al., 2013).
System performance evaluation allows an organization to understand the issues, or key drivers, of their service deliveries. Qualitative research techniques can be used to better understand a service through the customers' eyes, and to explore in depth their experiences and expectations. Such qualitative research can be supported by quantitative research to provide numerical measures of customer satisfaction and come up with statistically representative findings to assess the system performances and provide valuable information to decision makers to drive improved service quality (Zeraebruka, 2014). In this study, a customers' satisfaction survey and supply evaluation were carried out to obtain first hand data and information directly from customers using face to face interview/structured questionnaire. The overall purpose of the survey was to assess the customers' experiences and expectations regarding the water supply in llorin metropolis. The information is vital for development of appropriate decision support tools for improvement of services. The specific objectives of this study were to: obtain primary data on the mode of water supply distribution and corresponding issues from customers in order to establish the current level of water supply service delivery; and determine customers' level of satisfaction for water services. This will assist the decision makers in the water sector and authorities responsible for water supply to 
improve on the service delivery and the management of the system in urban cities of developing countries.

Providing too much water is a waste of money and taking too much water from a limited source may deprive people elsewhere of water with possible adverse environmental and health impacts (Reed, 2005). Hence, evaluation of municipal water supply becomes very essential and such evaluation needs to be reviewed on regular basis to enhance proper and effective management of the system. The demand for water depends on variables linked to human needs and behaviour and changes over time and space. It has been known that the variation in water demand is due to some factors, such as geographical location, types of community, population, cost, water management and economic status of the communities as well as the demographic characteristic of the area (Bouwa, 2000). Hence, that of supply could be as a result of similar factors since it is always a response to the demand. There are many factors that contribute to the total water consumed at household level. For example, Arbues, et.al (2003) analyzed several tariffs and their objectives and identified water price, income or household composition as crucial determinant of residential water use. Generally, the rate of water demand depends on the socio-economic standard of the people, the level of education and development, the nature of prevailing climate and hygienic characteristic of people (Largo et al., 1998; Arbues et al., 2003; Gilg and Bars, 2006; Mohammed, 2008; Basani et al., 2008; Bithas, 2008; Schleich and Hillenbrand, 2009).

According to Ajadi (2010), about 12 million gallons of water used to be pumped to the city per day against the 40 million gallon needed per day by the residents of llorin Township revealing a deficit of about 28 million gallon per day or $60 \%$ water shortfall between demand and supply to the city. His assessment shows that, water services by the state water agency (Kwara State Water Corporation or KWWC) were not satisfactory in terms of coverage, service connections, regularity of water supply. Exploiting alternative sources of water to augment their needs for water is an indication of water supply shortage as shown in the study of Musa and Fumen (2013). However, some areas were identified to enjoyed regular supply as a result of their locations or deliberate state priority policy. Also, the number of reservoirs available is insufficient to serve the increasing population with public water supply adequately and regularly. However, there were quite a number of boreholes and wells fitted with either hand pump or electric pumps within the city to complement the supply from the state water agency. Only few of these wells are known to be functioning as many have broken down due to lack of maintenance. Given all these considerations, there is therefore the need to evaluate the level of performance and variability in water supply to the city under study.

This study is therefore expected to increase the knowledge and understanding while also providing updated information on the urban water supply system serving the study area. The study outcome will include benchmark data for any further investigation with an overall goal of providing useful ideas that will enhance municipal water provision in developing countries. It will further serve as a working document to policy makers in the water sector and the Non-governmental Organizations that are involved in the task of water supply.

\section{MATERIALS AND METHODS}

The research methodology comprises of both field work and data analysis. Preliminary work conducted involved the review of the literature and development of data collection techniques and instruments before the commencement of field work. Reconnaissance survey preceded field data collection which involves discussions with the various stakeholders (consumers, supply agencies, policy makers, researchers, water vendors, etc) in the city water supply.

\section{Data Collection and Sampling Technique}

The data was collected with the aid of structured questionnaire. Household water use in selected houses situated in three different land use and residential areas was surveyed. The areas include: planned area (Irewolede Housing Estate); unplanned residential area (Oloje, Agbooba and Ipata residential area) and; Government Reserved Area (G.R.A.). These areas represent medium density, high density and the low density area/high income residential areas respectively (Ayanshola, 2013). The households were carefully selected to allow for the sampling of the different patterns of water use characteristics among the various segments of the city. A total number of 250 households were sampled. The study also involved metering of selected households to capture the average volume of water supplied to the households by KWWC. Super Italy water meters with multi-jet impeller were installed in selected houses whose locations were determined with the Global Positioning System (GPS).

\section{The Study Area}

Ilorin, the capital city of Kwara State (under North Central geopolitical zone of Nigeria) is located between latitudes $8^{\circ} 25^{\mathrm{N}} \mathrm{N}$ and $8^{\circ} 32^{\mathrm{N}} \mathrm{N}$ longitudes $4^{0} 30^{1} \mathrm{E}$ and $4^{0} 41^{1} \mathrm{E}$ (Figure 1). The town is located at southern part of Kwara State. Ilorin metropolis presently occupies an area of about $89 \mathrm{Km}^{2}$ (Adeleke, 2010). According to Ayanshola (2013), the population of Ilorin was estimated to be 606,533 in 1996 and 777,667 in 2007 spreading across three local governments (Ilorin East, Ilorin South and Ilorin West) (NPC, 2006). Three main rivers that flow through the city (Oyun, Asa, and Moro rivers) serve as a major source of water supply to the metropolis (Ayanshola, 2005).

\section{Data Analysis, Evaluation and Presentation}

The data collected from the field work conducted was analyzed using Statistical Packages (Stata/SE 8.0 and Microsoft EXCEL). The analysis was to evaluate the variables to be considered in examining the household water use variation within the metropolis. Variability Index $\left(V I_{x}\right)$ for some of the variables ( $x$-variable) was also determined and its value ranged between 0 and 1 . The closer the value of $V I_{x}$ to unity (1.0), the better the performance level of variables. The variability index was calculated using the following established mathematical expressions:

(i) Volumetric Variability Index $\left(\mathrm{VI}_{\mathrm{vol}}\right)$ :

$$
V I_{v o l}=\frac{\text { WaterUse }(l / c / d)}{120(l / c / d)}
$$

(ii) Hourly Variability Index $\left(V I_{h r}\right)$ : 
Ayanshola, Sule and Mandal

$$
V I_{h r}=\frac{\text { Supply Hour }(h r)}{24(h r)}
$$

(iii) Weekly Variability Index $\left(V I_{w k}\right)$ :

$$
V I_{w k}=\frac{\text { No of Supply Day Per Week }}{7 \text { days }}
$$

Sci. Technol. Arts Res. J., April-June 2015, 4(2): 252-258

The results of the analysis are presented graphically in 2-D and 3-D. Contour maps (3-D graph) were generated using Surfer 8 software to show the spatial variation of volume of water usage and frequency of household water use within the metropolis

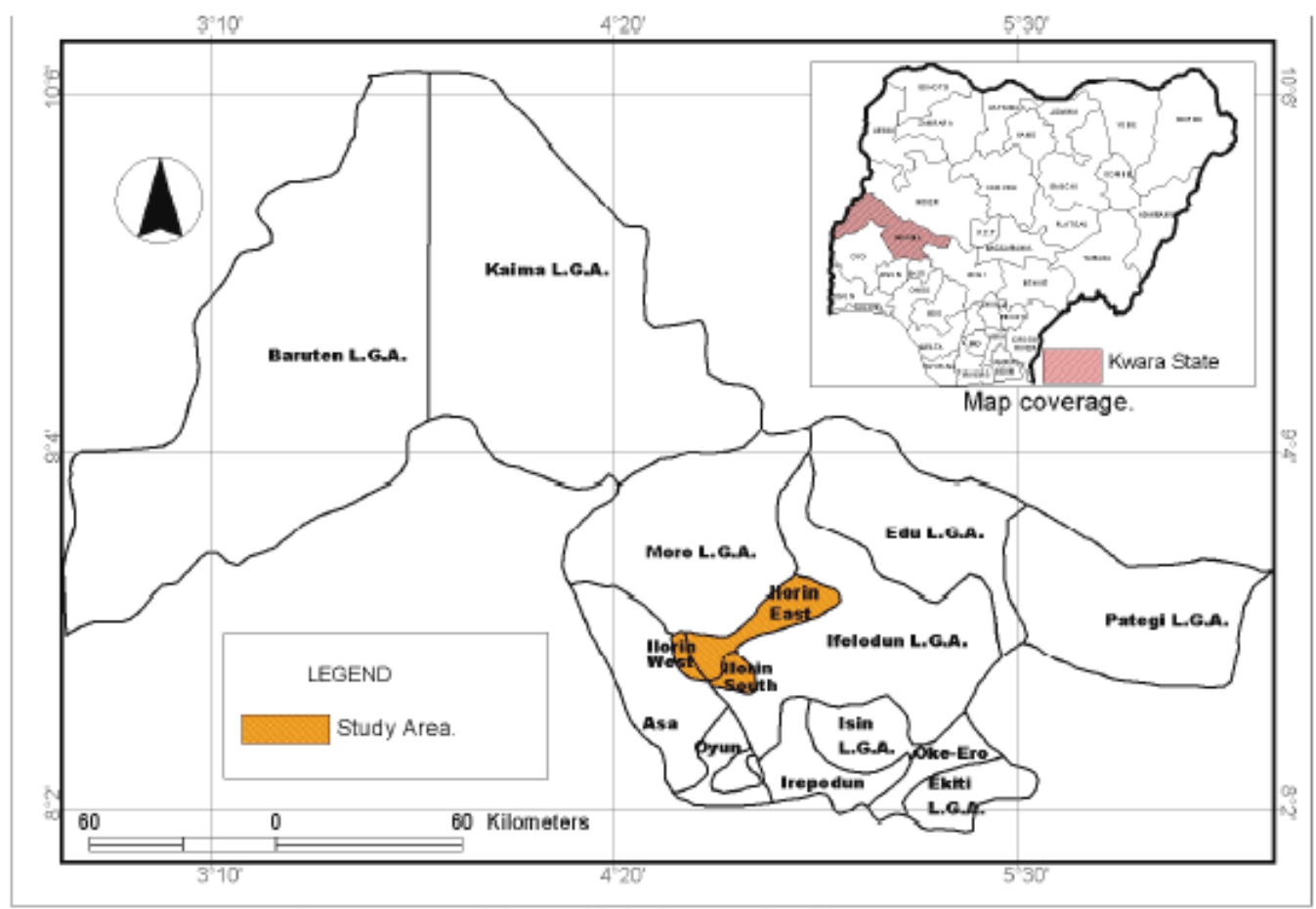

Figure 1: Map of Kwara State Showing the study Area (Source: Adebimpe, 2011)

\section{RESULTS AND DISCUSSION}

Water Use Rate and Frequency of Supply

The average minimum and maximum volume of water used as recorded were 0.82 and $372.14 \mathrm{l} / \mathrm{c} / \mathrm{d}$ respectively while the average was $139.44 \mathrm{l} / \mathrm{c} / \mathrm{d}$ as shown in Table 1. The coordinates of the locations of the installed water meters and the quantities of water used was recorded and used to generate the contour map showing the spatial variation of rate of water use at various locations within the metropolis (Figure 2). The measurement of household water use also showed that water is supplied to various locations at different number of days in a week as depicted in Figure 3. The results of the survey further showed that there is no household that had $100 \%$ supply (i.e. every day of week). However, $25 \%$ of the households surveyed received water five times per week. Also, only $10 \%$ of the households were served once a week. Comparing Figures 2 and 3 , it can be deduced that availability of water affects the use rate because, the contour maps show similar variation and pattern.

Table 1: Statistical summary of household water uses and number of supply days per Week

\begin{tabular}{lcc}
\hline Statistics & $\begin{array}{c}\text { Water Use } \\
\text { (I/c/d) }\end{array}$ & $\begin{array}{c}\text { No of Supply } \\
\text { Days per week }\end{array}$ \\
\hline Mean & 139.44 & 4 \\
Standard Deviation & 93.36 & 1.6 \\
Minimum & 0.82 & 1 \\
Maximum & 372.14 & 6 \\
\hline
\end{tabular}

Average daily water used was furthered classified into seven categories as shown in Figure 4. The analysis showed that household use rate between 51 and $100 \mathrm{l} / \mathrm{c} / \mathrm{d}$ were predominant (i.e. about $32 \%$ of total number of households surveyed). This was followed by households using between 151 to $200 \mathrm{l} / \mathrm{c} / \mathrm{d}$ (25\% of the total number of households surveyed). However, average household water use rate was found to be $139.44 \mathrm{l} / \mathrm{c} / \mathrm{d}$ as earlier mentioned which is higher than $120 \mathrm{l} / \mathrm{c} / \mathrm{d}$ recommended by $\mathrm{WHO}$ for developing countries urban cities. 

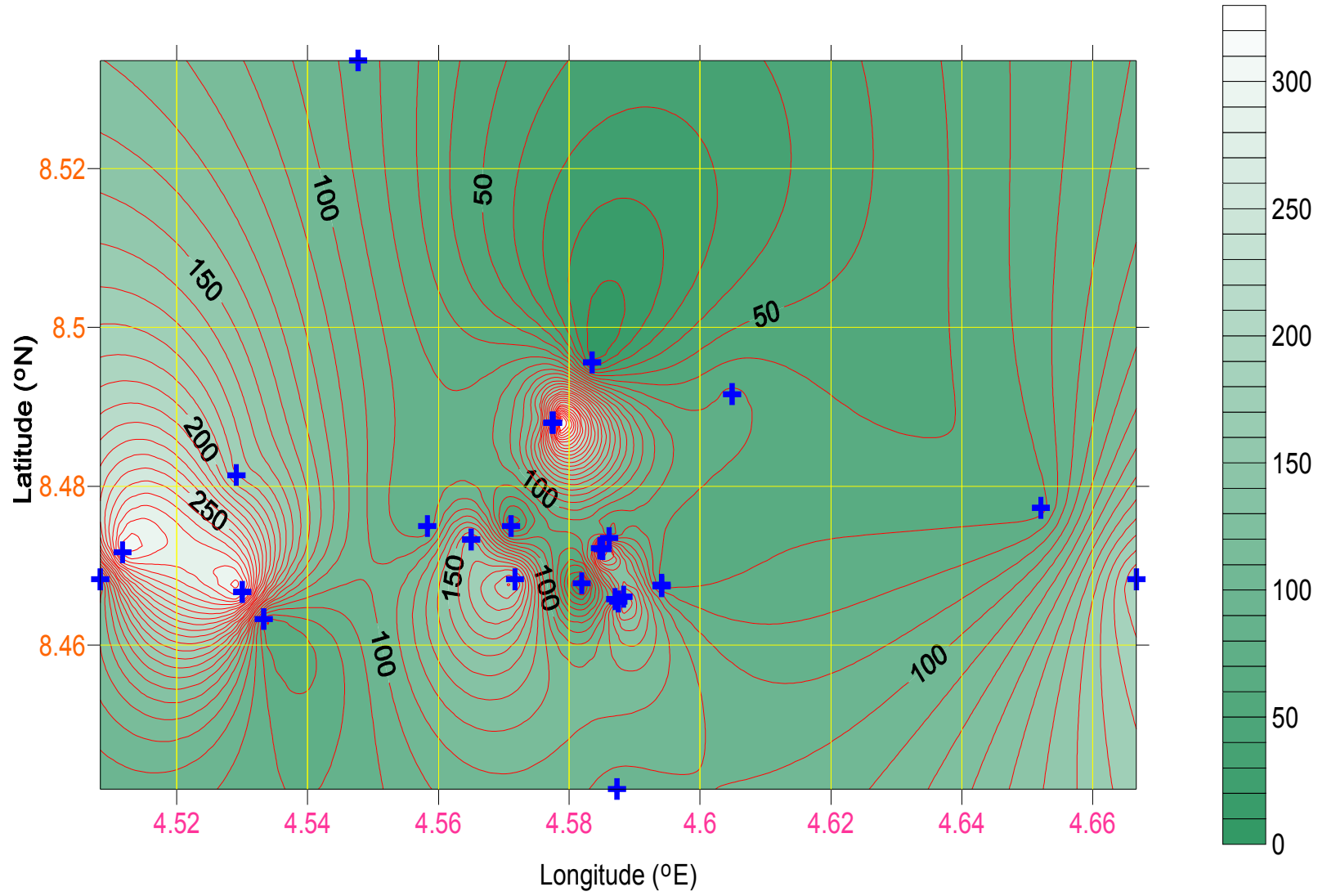

Figure 2: The spatial variation of household water use rate $(1 / c / d)$

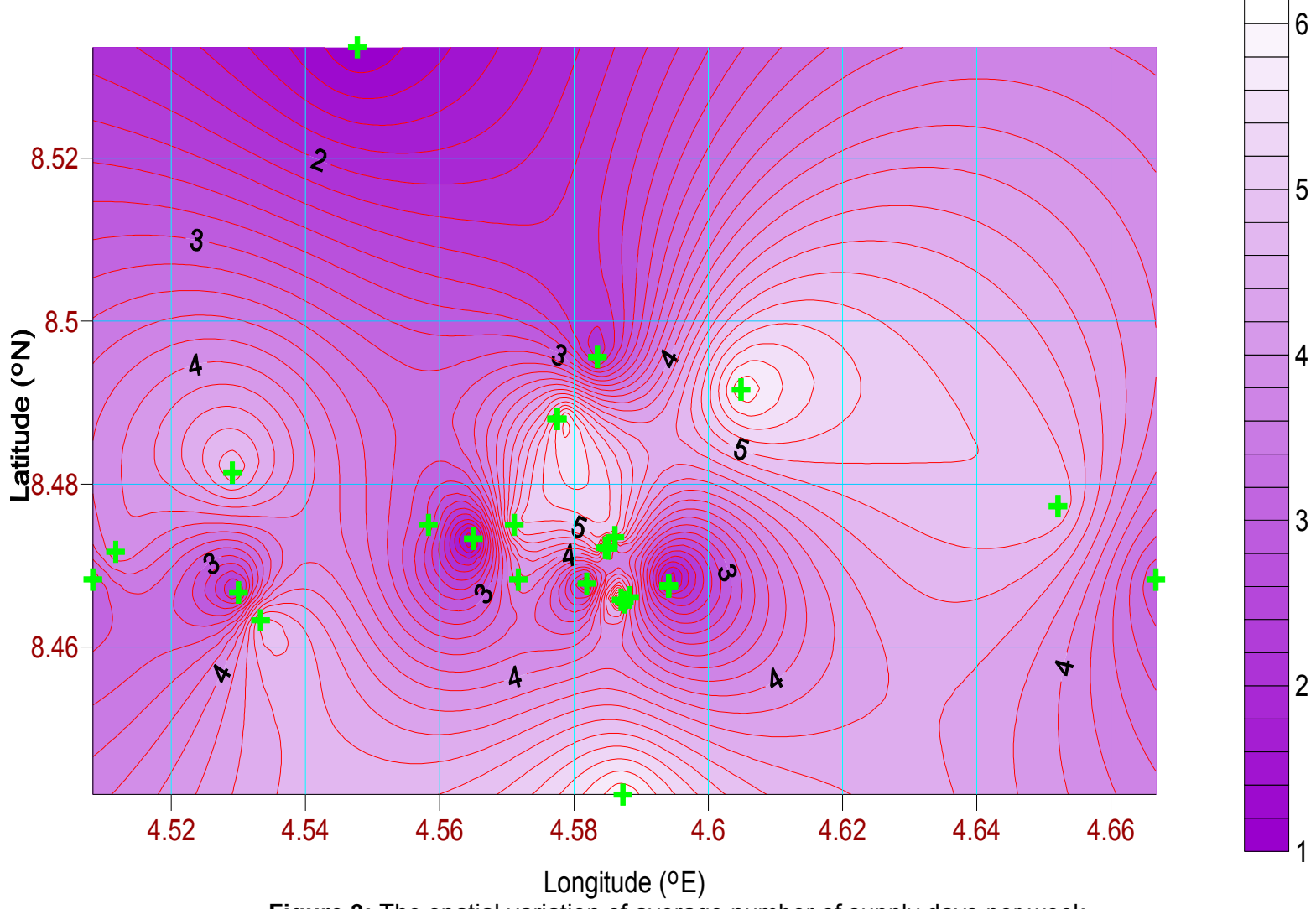

Figure 3: The spatial variation of average number of supply days per week 


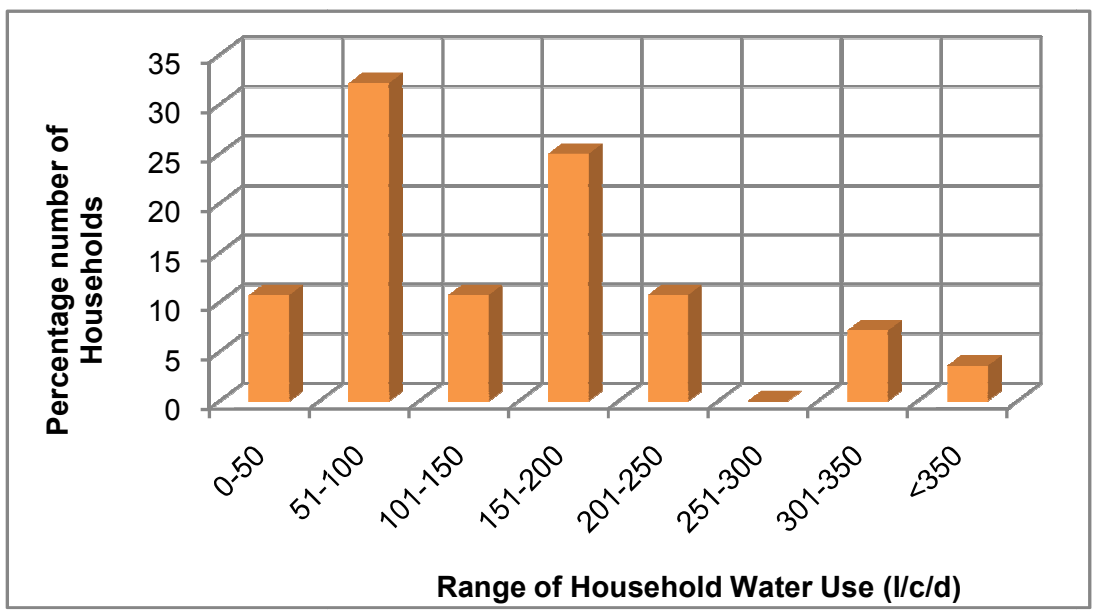

Figure 4: Average percentage household water use per capita per day

Variability Index of Supply

Daily and Hourly Variation of Supply

The result from the analysis shows that most of the houses receive their supply from municipal water supply for about 1 to 8 hours on supply days while 5 hours of supply (i.e. $V I_{h r}=0.21$ ) is the predominant duration of supply among the sampled houses. A curve peak is a clear indication that most of the households fall within this value of variability index. A few number of households (about $1.74 \%$ ) receive water for complete 24 hours on supply days. Detail of hourly variability index and percentage distribution are as shown in Figure 5.

\section{Weekly and Daily Variation of supply}

Once in a week supply pattern $\left(\mathrm{VI}_{\mathrm{wk}}=0.14\right)$ has the highest frequency of about $26 \%$ of the total sampled households considered. From the analysis, few households have their average weekly Variability Index of 0.57 (i.e. about $10.59 \%$ of the total households considered). The chart shown in Figure 8 has indicated that variability Index of weekly basis is inversely proportional to the percentage number of households. As the variability index is tending towards unity, the numbers of households is reducing. Detail of this analysis is as illustrated in the slope of the graph shown in Figure 6.

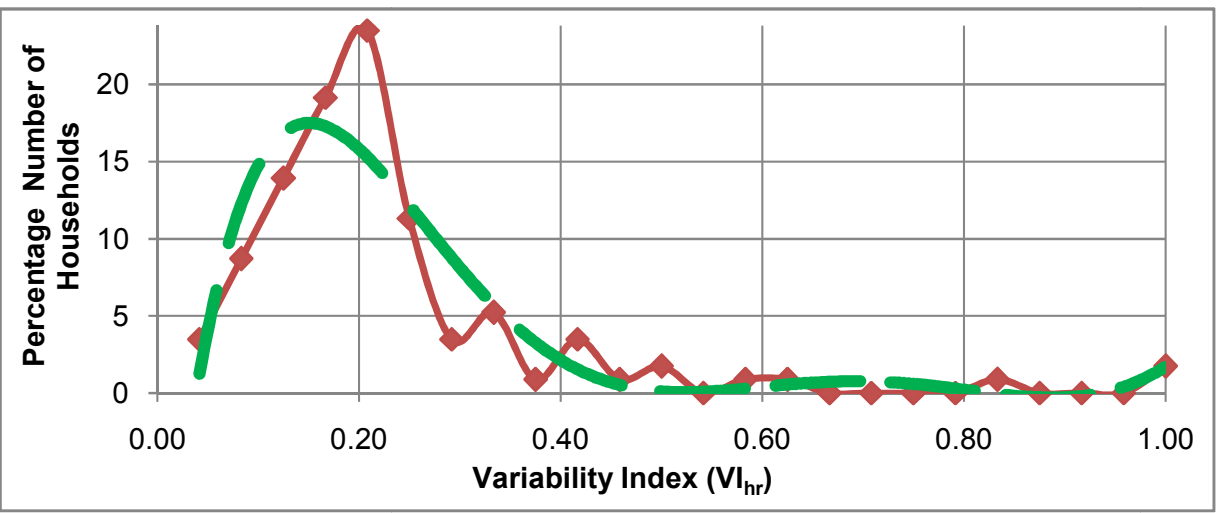

Figure 5: Hourly water supply variability level

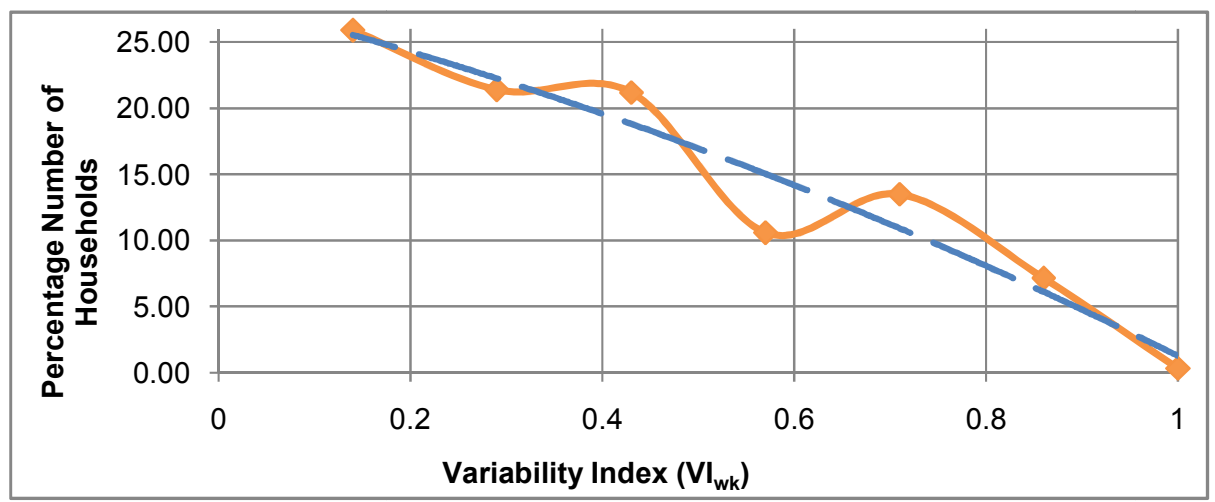

Figure 6: Weekly water supply variability level 


\section{Volumetric Variability Index}

Volumetric variability indices were determined and evaluated as represented in Figure 7.The graph indicates that a substantial percentage of households enjoyed regular supply. This may be as a result of their locations or the adoption of the state priority policy on supply to some areas (Musa and Fumen, 2013). In such households, water use is higher than $120 \mathrm{l} / \mathrm{c} / \mathrm{d}$, hence their Variability Index will be greater than one. Figure 7 shows that the volumetric variability index increases with the percentage number of households until it gets to its peak value of about 0.7 . The range of values that the optimum Variability Index can attain for the households is between 0.6 and 0.8 .

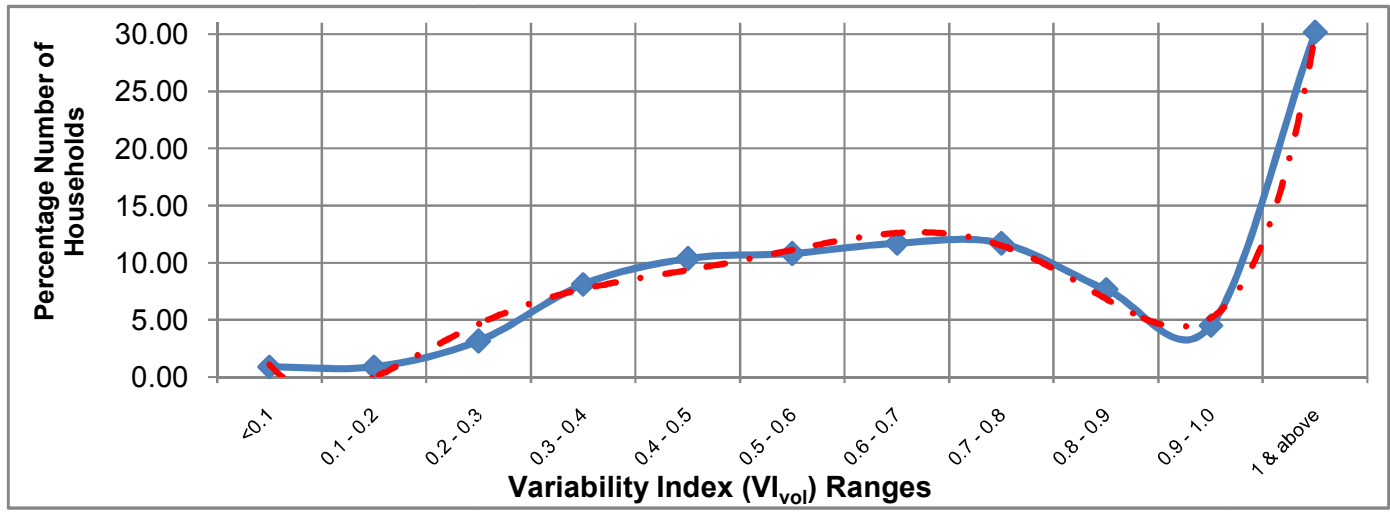

Figure 7: Volumetric variability index based on questionnaires

\section{Water Supply Quality Rating}

\section{Pressure}

Based on the consumers' perception among the households connected to municipal water supply, only 9 $\%$ are reported to be satisfied with water supply pressure. Over $65 \%$ are less satisfied and more than $25 \%$ are not satisfied with the supply pressure (see details illustration in Figure 8).

\section{Colour}

As illustrated in Figure 8, majority of the people in the households connected to municipal supply are satisfied with the colour of supplied water (about $64 \%$ of the total households connected). About $6 \%$ of the total households connected are not satisfied with the colour while few households are not sure of the water supply colour hence "can't say".

\section{Taste}

Just like in the case of colour, more than half of the total sampled households were satisfied with the taste of supplied water to the metropolis (about $58 \%$ ). About 11 $\%$ cannot rate the taste of the water while $8.39 \%$ have been reported not to be satisfied with the taste of the water. Detail of the analysis is as illustrated in Figure 8.

\section{Odour}

About $61 \%$ out of total households connected reported to be satisfied with the odour of the water while about $11 \%$ could not give any response on odour. More than $19 \%$ are not too satisfied with the odour and about 8 $\%$ are not satisfied. The details are illustrated in Figure 8.

\section{Cleanliness}

As reported by the households connected based on sampling, about $46 \%$ are satisfied with municipal water supply in term of cleanliness while about $10 \%$ are not satisfied. Also, about $7 \%$ cannot rate the municipal water supply in term of cleanliness. The detail analysis is as illustrated in Figure 8.

\section{Overall Quality}

Based on people perception as reported by the survey conducted, majority (about $42 \%$ of the total number sampled) believed that overall quality is less satisfactory. About $26.45 \%$ are satisfied with overall quality while about $16 \%$ were not able to give any rating in term of this measured parameter. Detail of this is also illustrated in Figure 8.

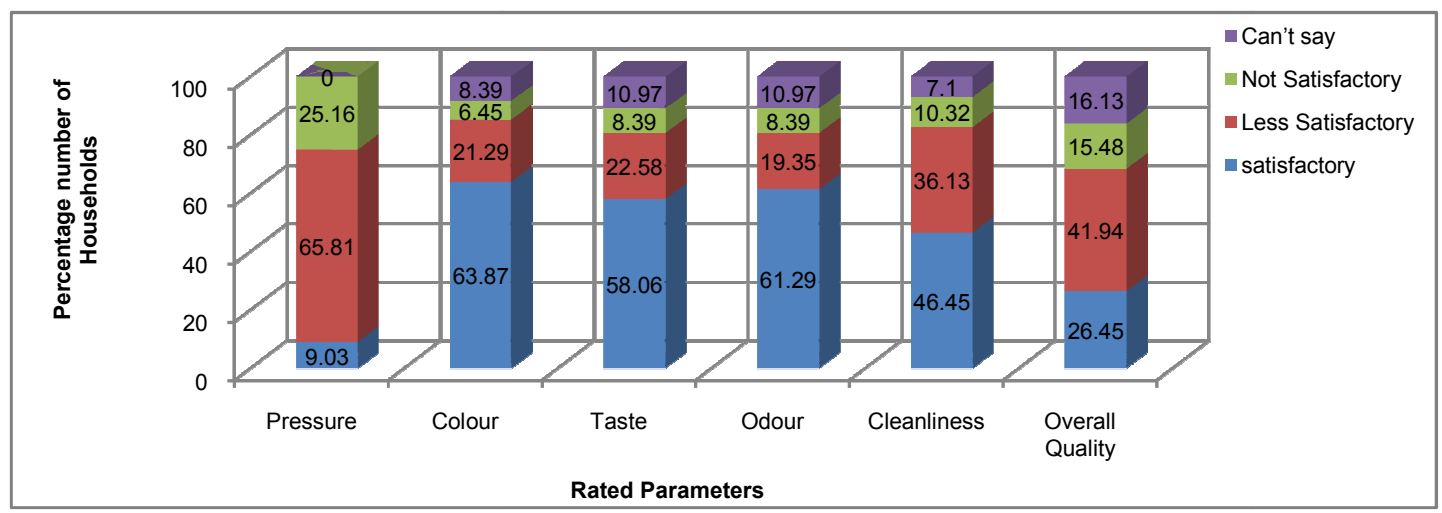

Figure 8: Municipal water Supply Rating 


\section{CONCLUSIONS}

This study has shown that the present water supply in Ilorin metropolis is grossly inadequate and the people are not satisfied with the situation. The estimated average daily water use was $86.22 \mathrm{l} / \mathrm{c} / \mathrm{d}$ which is lower than W.H.O. standard of $120 \mathrm{l} / \mathrm{c} / \mathrm{d}$ for developing nations. However, the measurement from installed water meters indicated that average water use can be as high as $139.44 \mathrm{l} / \mathrm{c} / \mathrm{d}$. The analysis of variability indices for various parameters examined showed that as the variability indices are tending towards unity, the percentage number of households was decreasing. There is the need to put in place a framework to enhance improvement of water supply to the metropolis in order to achieve an index tending towards unity. The metering of pipe water supply to houses for accurate data collection on water use is recommended so that the necessary baseline data on effective water demand/supply will be available. This will allow further investigation on supply and demand management with an overall goal of providing useful ideas to improve municipal water supply in developing countries.

\section{Acknowledgments}

The authors wish to thank Science and Technology Education Post-Basic (Step-B) project, Federal Ministry of Education, Federal Republic of Nigeria for Innovators of Tomorrow (I.O.T.) grant used to acquire the necessary equipment for the field study. We also acknowledge the Council of Scientific and Industrial Research (CSIR), India and The World Academy of Science (TWAS), Italy for the award of CSIR-TWAS Postdoctoral Fellowship programme to the lead author. The fellowship was undertaken at the CSIR-National Institute of Science, Technology and Development Studies (NISTADS), New Delhi, India where this article was prepared.

\section{Conflict of Interest}

Authors declared no conflict of interest.

\section{REFERENCES}

Adebimpe, R.U. (2011). Climate changes related disasters and vulnerability: an appraisal of the Nigerian policy environment. Environmental Research Journal 5(3): 97103.

Adeleke, O.O. (2010). Empirical modelling of delays at traffic warden controlled urban intersections: case study of Ilorin, Nigeria, Unpublished PhD Thesis Submitted to Department of Civil Engineering, University of Ilorin, Ilorin, Nigeria.

Ajadi, B.S. (2010). Portable water availability and use pattern in Ilorin metropolis, Nigeria. Global Journal of Human Social Science 10(6): 44-50

Arbues, F., Garcia-Valinas, M.A. and Martnez-Espineira, R. (2003). Estimation of residential water demand: a stateof-the-art review. Journal of Socio-Economics 32: 81-102.

Ayanshola, A.M. (2005). Pressure distribution analysis in zonal water supply pipe network: a case study of llorin metropolis, Unpublished M. Eng. Project Report,
Department of Civil Engineering, University of Ilorin, Ilorin, Nigeria.

Ayanshola, A.M. (2013). Evaluation of supply reliability and sustainability of household water use in Ilorin, Kwara State, Nigeria, Unpublished Ph.D. Thesis, Department of Civil Engineering, Faculty of Engineering and Technology, University of Ilorin, Ilorin, Nigeria.

Ayanshola, A.M., Sule, B.F. and Salami, A.W. (2013); Evaluation of Willingness to Pay for Reliable and Sustainable household Water Use in Ilorin, Nigeria. Ethiopian Journal of Environmental Studies and Management 6(6): 754-762.

Basani, M., Isham, J. and Reilly, B. (2008). The determinant of water connection and water consumption: empirical evidence from a Cambodian household survey. World Development 36(5): 953-968.

Bithas, K. (2008). The Sustainable Residential Water Use: Sustainability, efficiency and social equity, the European experience, Ecological Economics 68: 221-229.

Gilg, A. and Barr, S. (2006). Behavioural attitudes towards water saving? evident from a study of environmental actions. Ecological Economics 57: 400-414.

Gleick, H.P. (1996), Basic water requirement for human activities: meeting basic needs. Water International 21(2): 83-92.

Largo, F.M., Inocencie, A.B. and David, C.C. (1998). Understanding household water demand for Cebu, Philippine Institute for Development Studies, Discussion paper series No. 98-41.

Mohammed, A.S. (2008). Water demand management in Egypt: policy, objectives and strategy measure. Physics and Chemistry of the Earth 25(23): 243-249.

Musa, J.J. and Fumen, G.A. (2013). Assessment of potable water supply sources in Ilorin metropolis, Kwara state, Nigeria International Journal of Agriculture Research, Innovation \& Technology 3 (1): 1-4.

Okonkwo, J.O. (2010). Sanitation, portable water supply and environmental protection: benefits, progress and issues for sustainability in developing countries. AISA POLICYbrief, No. 23.

Reed, B. (2005). Minimum water quantity needed for domestic use in emergencies, WHO technical notes for emergencies, WEDC, Loughborough University, Leicestershire, UK, Technical Note No. 9, pp. 1-4.

Schleich, J. and Hillenbrand, T. (2009). Determinants of residential water demand in Germany. Ecological Economics 68(6): 1756-1769.

Tabieh, M., Salman, A., Al-Karablieh, E., Al-Qudah, H. and Al-khatib, Y. (2012). The residential water demand function in Amman- Zarka basin in Jordan, Wulfenia Journal (11): 324-333.

Zeraebruka, K.N., Mayabib, A.O., Gathenyac, J.M. and Tsige, Z. (2014). Assessment of level and quality of water supply service delivery for development of decision support tools: case study asmara water supply. International Journal of Sciences: Basic and Applied Research 14(1): 93-107. 